\title{
Bacillus subtilis NRRL B-30408: A potential inoculant for crops grown under rainfed conditions in the mountains
}

\author{
M.K. Malviya ${ }^{1}$, A. Sharma ${ }^{2}$, A. Pandey ${ }^{1 *}$, Rinu K ${ }^{3}$, P. Sati ${ }^{1}$, and L.M.S. Palni ${ }^{1}$ \\ ${ }^{1}$ Biotechnological Applications, G.B. Pant Institute of Himalayan Environment and Development, Kosi- \\ Katarmal, Almora, Uttarakhand, India, 263 643. ${ }^{*}$ Corresponding author: anita@gbpihed.nic.in. ${ }^{2}$ Microbial \\ Culture Collection, National Center for Cell Science, Pune, Maharashtra, India, 411 007. ${ }^{3}$ The Sartorius-stedim \\ Biotechnology Laboratory, University of North Carolina, Pembroke, NC 28372.
}

\begin{abstract}
On-farm inoculation trials have been conducted to evaluate the potential of Bacillus subtilis NRRL B-30408 in respect of plant growth promotion, for two consecutive years, under rainfed conditions at a mountain location in the Indian Himalayan Region (IHR). For this, one cereal (Oryza sativa) and two millets (Eleusine coracana and Echinochloa frumentacea), were used as test crops. Observations were recorded in terms of plant growth, yield, chlorophyll content, and root colonization by various groups of microorganisms. Positive influence of bacterial inoculation on all the three crops, statistically significant in case of most parameters examined as compared to untreated controls, was recorded in both the years. There was a significant increase in chlorophyll concentration in leaves of inoculated plants. While the bacterial inoculation stimulated the free living bacterial and actinomycetes populations in the rhizosphere, the fungal population was somewhat suppressed; indicative of the antifungal property of the inoculant. The treatment also enhanced the colonization of arbuscular mycorrhizae (AM), and the endophytes associated with the roots. In conclusion, the plant growth promotion, recorded as a result of microbial inoculation, is attributed to the microbial shift in the native microflora of the rhizosphere. Based on the results of this field study, B. subtilis NRRL B-30408 can be proposed as an efficient bioinoculant for the hill crops, grown under rainfed conditions of the mountain ecosystem. The main aim of this study was on farm demonstration of the microbe based technology with peoples' participation, with a view of adoption of the technology by the farmers.
\end{abstract}

Keywords: Bacillus subtilis NRRL B-30408, yield, root colonization, chlorophyll content, people's participation. 


\section{Introduction}

The classical work of Hiltner (1904) had indicated two major areas of rhizosphere research of applied value: (i) rhizosphere in relation to plant nutrition, growth, and development, and (ii) influence of rhizosphere phenomena on pathogens with emphasis on biocontrol. Subsequently, a class of rhizosphere microorganisms, closely associated with plant roots, was recognized as plant growth promoting rhizobacteria (PGPR) (Kloepper et al., 1989). The review by Rovira (1991) on rhizosphere biology with focus on PGPR, highlighted the variable results obtained by different researchers. Further, Lucy et al. (2004), while looking at the work conducted, on crop plants over a period of 25 years, to see the effect of free living rhizobacteria has also mentioned the inconsistence results obtained between laboratory, greenhouse, and field based studies.

Increased global preference for natural "organics" and the need to reduce the use of chemical fertilizers has catalyzed research on development of biological fertilizers in recent times. Isolation of microorganisms, screening for desirable characters, selection of efficient strains, production of inocula and formulations that are easy to store and transport are all important steps in the development of this environment friendly and sustainable technology. Besides the direct benefits of the use of plant growth promoting microorganisms, the ecological and rhizosphere competence, and their effect on the native rhizosphere microorganisms, are also important in selecting suitable microbial inoculants, for a particular environment (Pandey et al., 1998).

A series of experiments have been conducted for developing microbial inoculants, specifically for colder regions. The initial on-farm experiments, carried out at various elevations, indicated the necessity to take care of the ecological specificity of the microorganisms, and the need for using native microor- ganisms as microbial inoculants for field applications (Pandey et al., 1998). Further, this concept was followed during several laboratory and field based screenings, leading finally to the selection and development of formulations using the psychrotolerant species of Pseudomonas, and the endospore forming $\mathrm{Ba}$ cillus (Pandey et al., 2001 a, b; 2002; 2004; Kumar et al., 2007; Trivedi et al., 2007; Rinu and Pandey, 2009; Trivedi et al., 2012) for application in agricultural crops. In the present study, on-farm inoculation trials have been conducted, with participation of the local farmers, on three popular agricultural crops grown in the hills. The benefits were demonstrated through comparative assessment, made between the control and inoculated plots; evaluations were based on plant growth, yield related parameters, and colonization of the rhizosphere associated microorganisms. It is hoped that such trials involving the farmers would lead to acceptance of this technology for wider adoption.

\section{Materials and methods}

\subsection{Study location and test crops}

About 85 per cent of people in the Indian Central Himalaya practice rainfed subsistence agriculture. The land holdings are small, fragmented and on terraced slopes; per capita cultivated land is 0.2 ha and mixed cropping is common under such conditions. Over 40 crop species, comprising of cereals, millets, pseudocereals, pulses, oil seeds, tubers, bulbs and spices are cultivated (Farooquee and Maikhuri, 2009). A number of landraces of rice are cultivated in the rainfed upland farming system of Uttarakhand Himalaya (Agnihotri et al., 2000).

Three villages (Katarmal, Panchgaun, and Bari) in district Almora, Uttarakhand, India, were selec- 
ted for conducting these field experiments. A total of three crops, comprising of one cereal (Oryza sativa L., common name- rice, local name dhan) and two millets (Eleusine coracana L. Gaertn., common name- finger millet; local name- Mandua or Khoda and, Echinochloa frumentacea (common name- barnyard millet; local name Madira or Jhangora) were used as test crops. E. coracana is used for making flour while $E$. frumentacea is used as a substitute of rice. The crop residue is used for fodder and fuel. The selection of crops was done on the basis of their importance for the local farmers. The inoculation trials were carried out on farmers' fields, for two consecutive years in 2008 and 2009.

\subsection{Soil characteristics}

Soil characteristics are summarized in Table 1. Phosphorus $(\mathrm{P})$ and Potassium $(\mathrm{K})$ were determined following the standard methods (Allen, 1974), while the total Carbon $(\mathrm{C})$ and Nitrogen $(\mathrm{N})$ were determined using CHNS Analyzer Vario EL III (Elementar, Germany).

Table 1. Study sites and soil properties.

\begin{tabular}{|c|c|c|c|c|}
\hline Study site & Longitude & Latitude & $\begin{array}{l}\text { Altitude } \\
\text { (amsl)* }\end{array}$ & Soil characteristics \\
\hline Katarmal & N $28^{\circ} 37^{\prime} 33.0^{\prime \prime}$ & Е $079^{\circ} 38^{\prime} 9^{\prime \prime}$ & $1159 \mathrm{~m}$ & $\begin{aligned} \mathrm{pH} \text { 6.5, moisture: } 29 \% \\
\mathrm{C}=1.56 \%, \mathrm{~N}=0.113 \%, \mathrm{P}=0.029 \%, \mathrm{~K}=1.28 \%\end{aligned}$ \\
\hline Panchgaon & N $29^{\circ} 38^{\prime} 59.0^{\prime \prime}$ & E $079^{\circ} 37^{\prime} 12.9^{\prime \prime}$ & $1205 \mathrm{~m}$ & $\begin{array}{c}\text { pH } 6.3 \text {, moisture: } 35 \% \\
\mathrm{C}=1.41 \%, \mathrm{~N}=0.104 \%, \mathrm{P}=0.035 \%, \mathrm{~K}=1.30 \%\end{array}$ \\
\hline Bari & 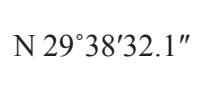 & E $079^{\circ} 37^{\prime} 48.1^{\prime \prime}$ & $1198 \mathrm{~m}$ & $\begin{array}{c}\text { pH } 6.4 \text {, moisture: } 39 \% \\
\mathrm{C}=1.83 \%, \mathrm{~N}=0.144 \%, \mathrm{P}=0.037 \%, \mathrm{~K}=1.80 \%\end{array}$ \\
\hline
\end{tabular}

* above mean sea level.

\subsection{Bacterial inoculant}

Bacillus subtilis, maintained at $-20{ }^{\circ} \mathrm{C}$ in Tryptone Yeast extract (TY) broth containing 20\% (v/v) glycerol, was used for the seed inoculations. The bacterium was originally isolated from a mountain location, following heavy snowfall, and selected for moderate phosphate solubilization and strong antagonistic properties (Pandey et al., 1997; Chaurasia et al., 2005). Subsequently, it has been evaluated for plant growth promotion, using agricultural, forest and tissue culture raised plant species, through laboratory as well as field based assays
(Pandey et al., 2000; Trivedi et al., 2007, Rinu and Pandey, 2009). The isolate has been accessioned (NRRL B-30408) at the Agricultural Research Service (ARS), Patent culture collection, United States Department of Agriculture, Illinois, under the Budapest Treaty. Suspension culture of $B$. subtilis was raised in TY broth for $48 \mathrm{~h}$ with shaking $(120 \mathrm{rpm})$ at $25^{\circ} \mathrm{C}$. The bacterial cells were then suspended in $10 \%(\mathrm{w} / \mathrm{v})$ mixture of a suitable sticker (raw sugar) in water $\left(10^{6}\right.$ colony forming units (cfu) $\mathrm{ml}^{-1}$ ). One hundred $\mathrm{mL}$ of this suspension was mixed with $150 \mathrm{~g}$ sterilized charcoal, and the slurry was used as seed coating. 


\subsection{Experimental setup}

The seed sowings were done in the month of april while the crops were harvested in October. Seeds (100 g) were mixed with the inoculant slurry (described above) in a $500 \mathrm{~mL}$ capacity tray. The control seeds were also mixed with the slurry (containing $10 \%$ sticker and $150 \mathrm{~g}$ charcoal, without the bacterium). Before mixing, the seeds were rinsed ( $\mathrm{x} 4$ ) with sterile distilled water. The trays were kept at room temperature for $4 \mathrm{~h}$, allowing the coated bacteria to colonize during germination. For field assays, separate plots were prepared for each treatment. The plot size varied and ranged between 10-14 m x 3-5 m, depending on the size of the terrace. Only two crops were sown in village Bari, as per choice of the farmers. The plots were prepared in a randomized block design pattern, for the replicates. The plots for different treatments were separated from each other by an adequate gap between the plots. Approximately $100 \mathrm{~kg}$ farmyard manure was mixed in each plot as per normal practice. In the first year (2008), average maximum and minimum temperature, and rainfall during the cropping season (April to October) were $28.0^{\circ}$ and 16.5 ${ }^{\circ} \mathrm{C}$, and $791.4 \mathrm{~mm}$, respectively. In the second year (2009) the same were $28.2^{\circ}$ and $15.7^{\circ} \mathrm{C}$, and 927.2 $\mathrm{mm}$, respectively.

\subsection{Plant growth and yield}

For recording growth parameters, ten plants were randomly harvested from the respective plots for each crop during flowering (120 days after sowing) from both the control and inoculated plots, and washed with running water. First, the root and shoot length was recorded; the roots were then cut off, and the root and shoot portions were dried separately at $70{ }^{\circ} \mathrm{C}$ for $72 \mathrm{~h}$, for each plant. Another ten representative plants were randomly harvested from control and inoculated plots at full maturity to determine yield related parameters. The plants were dried at $70{ }^{\circ} \mathrm{C}$ for $72 \mathrm{~h}$ and weighed for calculating the biomass; seed weight (yield; from 10 spikes) was also recorded. Harvest index (HI) was calculated using the formula: $\mathrm{HI}=$ economic yield $\mathrm{x}$ 100 / biological yield.

\subsection{Chlorophyll content of leaves}

For estimation of chlorophyll content, $1 \mathrm{~g}$ fresh flag leaves were cut into small pieces, made into a pulp with mortar and pestle with addition of $20 \mathrm{~mL}$ of $80 \%$ $(\mathrm{w} / \mathrm{v})$ acetone. Samples were centrifuged at $5000 \mathrm{x} \mathrm{g}$ for $5 \mathrm{~min}$ and the supernatant was transferred to a 100 $\mathrm{mL}$ volumetric flask. The residue was mixed with 20 $\mathrm{mL}$ of $80 \%$ acetone, the extract was centrifuged and the supernatant was transferred to volumetric flask. This was repeated until the residue became colourless. The volume was made up to $100 \mathrm{~mL}$ with $80 \%$ acetone. The absorbance of the solution was read at $645 \mathrm{~nm}$ and $663 \mathrm{~nm}$ against solvent (80\% acetone) blank and the chlorophyll content was calculated by standard method.

\subsection{Rhizosphere microorganisms}

The estimations were made on the culture dependant free living rhizosphere microorganisms, and colonization of roots by AM fungi and the endophytes. Three groups of microorganisms, viz. bacteria, actinomycetes and fungi were enumerated, using the serial dilution technique. TY agar, Actinomycetes agar and Potato dextrose agar were used for enumeration of bacteria, actinomycetes and fungi, respectively in year 2 . Serially diluted plates were observed for colonies, after incubation at $25^{\circ} \mathrm{C}$ for 1 week.

The root colonization studies by AM fungi and other endophytes were carried out at the time of flowering on ten randomly harvested plants. The roots 
were washed thoroughly with running tap water. Subsequently, the lateral roots were taken for observations on fungal colonization. Twenty-five (randomly taken from five control and five inoculated plots) root samples each were cut into pieces of $1 \mathrm{~cm}$ length, and treated with $10 \% \mathrm{KOH}$ at $90{ }^{\circ} \mathrm{C}$ for $1 \mathrm{~h}$, then washed with water to remove $\mathrm{KOH}$ and treated with alkaline $\mathrm{H}_{2} \mathrm{O}_{2}$ for 15 min. Afterwards $\mathrm{H}_{2} \mathrm{O}_{2}$ was removed by washings with water and the root samples were acidified with $1 \% \mathrm{HCl}$ for $10 \mathrm{~min}$. The $\mathrm{HCl}$ was drained, and the root samples were stained with $0.1 \%$ trypan blue at $90{ }^{\circ} \mathrm{C}$ for $30 \mathrm{~min}$ and observed under a microscope (Nikon-Optiphot 2, Japan). The number of $\mathrm{AM}$ and other endophytic fungi counted in the root samples were recorded, and the per cent AM colonization was calculated using the formula: number of positive root pieces $\times 100$ / total number of root pieces observed. Observations were also recorded on endophytes in the same root segments and \% colonization was calculated as for AM colonization.

\subsection{Statistics}

The excel program of Microsoft Windows 2003 professional was used to calculate means and standard deviations. ANOVA was performed to determine significant differences between control and inoculated plants.

\section{Results}

\subsection{Plant growth parameters}

Positive influence of $B$. subtilis NRRL B-30408 inoculation was recorded on the growth and yield parameters in all the crops, grown at three villages (only two crops at Bari). These results, along with the statistical analyses, are presented in Tables $2 \mathrm{a}-\mathrm{c}$; results found to be statistically significant $(p<0.05 \%)$ have been marked by an asterisk. In case of Oryza sativa, in village Katarmal, shoot and root length, biomass and yield in inoculated plants was found to increase up to $8.2,15.6,22.9$ and $6.6 \%$, respectively, over control in Year 1. While in year 2 shoot and root length, biomass and yield increased up to $11.2,14.4,31.8$ and $16.6 \%$, over control. In village Panchgaon, shoot and root length, biomass and yield were found to increase up to $19.6,18.7,22.8$ and $11.1 \%$, respectively, in year 1 . In Year 2, shoot and root length, biomass and yield increased up to $11.1,24.4,31.2$ and $10.5 \%$, respectively, over control. In village Bari, shoot and root length, biomass and yield increased up to 19.1, 17.4, 19.9 and $10.7 \%$ in Year 1, while in Year 2 shoot and root length and biomass and yield increased up to $11.9,17.3,38.5$ and $10.0 \%$, respectively, over control (Table 2a).

Table 2a. Influence of bacterial inoculation on growth and yield related parameters of Oryza sativa recorded in three villages.

\begin{tabular}{lcccccccc}
\hline \multicolumn{1}{c}{ Year 1 } \\
\hline Treatment & $\begin{array}{c}\text { Shoot } \\
\text { length }(\mathrm{cm})\end{array}$ & $\begin{array}{c}\text { Root length } \\
(\mathrm{cm})\end{array}$ & $\begin{array}{c}\text { Biomass } \\
(\mathrm{g})\end{array}$ & $\begin{array}{c}\text { Yield } \\
(\mathrm{g})\end{array}$ & $\begin{array}{c}\text { Shoot length } \\
(\mathrm{cm})\end{array}$ & $\begin{array}{c}\text { Root length } \\
(\mathrm{cm})\end{array}$ & $\begin{array}{c}\text { Biomass } \\
(\mathrm{g})\end{array}$ & $\begin{array}{c}\text { Yield } \\
(\mathrm{g})\end{array}$ \\
\hline \multicolumn{7}{c}{ Katarmal } \\
\hline Control & $82.62 \pm 9.20$ & $11.33 \pm 1.98$ & $3.79 \pm 0.99$ & $1.46 \pm 0.20$ & $114 \pm 6.20$ & $12.47 \pm 1.98$ & $7.52 \pm 1.98$ & $1.57 \pm 0.30$ \\
Inoculated & $90.03 \pm 7.26 *$ & $13.40 \pm 2.41$ & $4.88 \pm 1.01$ & $1.58 \pm 0.23$ & $128.5 \pm 2.63 *$ & $14.55 \pm 3.80$ & $11.04 \pm 9.14^{*}$ & $1.82 \pm 0.23^{*}$ \\
ANOVA & $F_{l, 18}=4.57$ & $F_{l, 18}=2.44$ & $F_{l, 18}=5.94$ & $F_{l, 18}=5.94$ & $F_{l, 18}=9.46$ & $F_{l, 18}=1.59$ & $F_{1,18}=11.37$ & $F_{l, 18}=4.27$ \\
& $p=0.046$ & $p=0.132$ & $p=0.025$ & $p=0.025$ & $p=0.006$ & $p=0.22$ & $p=0.003$ & $p=0.053$ \\
\hline \multicolumn{7}{c}{ Panchgaon } \\
\hline Control & $84.22 \pm 6.87$ & $13.04 \pm 2.22$ & $4.45 \pm 0.81$ & $1.67 \pm 0.30$ & $111.8 \pm 8.18$ & $14.2 \pm 2.92$ & $7.72 \pm 1.53$ & $1.76 \pm 0.20$ \\
Inoculated & $104.8 \pm 7.36^{*}$ & $16.14 \pm 2.90^{*}$ & $5.76 \pm 1.76$ & $1.87 \pm 0.15$ & $125.8 \pm 12.76^{*}$ & $18.8 \pm 2.62 *$ & $11.29 \pm 1.14 *$ & $1.93 \pm 0.19^{*}$ \\
\hline
\end{tabular}




\begin{tabular}{|c|c|c|c|c|c|c|c|c|}
\hline \multicolumn{5}{|c|}{ Year 1} & \multicolumn{4}{|c|}{ Year 2} \\
\hline Treatment & $\begin{array}{c}\text { Shoot } \\
\text { length }(\mathrm{cm})\end{array}$ & $\begin{array}{l}\text { Root length } \\
(\mathrm{cm})\end{array}$ & $\begin{array}{l}\text { Biomass } \\
(\mathrm{g})\end{array}$ & $\begin{array}{l}\text { Yield } \\
(\mathrm{g})\end{array}$ & $\begin{array}{l}\text { Shoot length } \\
(\mathrm{cm})\end{array}$ & $\begin{array}{l}\text { Root length } \\
(\mathrm{cm})\end{array}$ & $\begin{array}{l}\text { Biomass } \\
(\mathrm{g})\end{array}$ & $\begin{array}{l}\text { Yield } \\
(\mathrm{g})\end{array}$ \\
\hline ANOVA & $\begin{array}{c}F_{1,18}=12.51 \\
p=0.002\end{array}$ & $\begin{array}{c}F_{1,18}=12.39 \\
p=0.002\end{array}$ & $\begin{array}{c}F_{1,18}=4.56 \\
p=0.466\end{array}$ & $\begin{array}{c}F_{1,18}=3.18 \\
p=0.091\end{array}$ & $\begin{array}{c}F_{1,18}=2.66 \\
p=0.011\end{array}$ & $\begin{array}{c}F_{1,18}=3.51 \\
p=0.077\end{array}$ & $\begin{array}{c}F_{1,18}=33.83 \\
p=1.65\end{array}$ & $\begin{array}{c}F_{1,18}=3.59 \\
p=0.073\end{array}$ \\
\hline \multicolumn{9}{|c|}{ Bari } \\
\hline Control & $86.87 \pm 7.36$ & $13.74 \pm 2.81$ & $5.91 \pm 1.34$ & $1.75 \pm 0.12$ & $125.87 \pm 8.91$ & $16.74 \pm 2.37$ & $7.86 \pm 2.07$ & $1.83 \pm 0.11$ \\
\hline Inoculated & $107.46 \pm 5.92 *$ & $16.68 \pm 1.92 *$ & $7.38 \pm 1.38 *$ & $1.96 \pm 0.14$ & $142.8 \pm 12.80^{*}$ & $20.23 \pm 2.37 *$ & $12.78 \pm 2.16^{*}$ & $2.02 \pm 0.11 *$ \\
\hline ANOVA & $\begin{array}{c}F_{1,18}=5.96 \\
p=0.025\end{array}$ & $\begin{array}{c}F_{1,18}=9.38 \\
p=0.006\end{array}$ & $\begin{array}{c}F_{1,18}=5.36 \\
p=0.032\end{array}$ & $\begin{array}{c}F_{l, 18} \\
=11.95 \\
p=0.002\end{array}$ & $\begin{array}{c}F_{1,18}=9.12 \\
p=0.007\end{array}$ & $\begin{array}{c}F_{1,18}=2.66 \\
p=0.11\end{array}$ & $\begin{array}{c}F_{1,18}=26.50 \\
p=6.74\end{array}$ & $\begin{array}{c}F_{1,18}=8.34 \\
p=0.009\end{array}$ \\
\hline
\end{tabular}

*significant at $p<0.05 \%$, values are the means $\pm \mathrm{SD}(\mathrm{n}=10)$.

In case of Eleusine coracana in village Katarmal shoot and root length, biomass and yield in inoculated plants were found to increase up to 10.2, 24.0, 26.5 and $14.5 \%$ in Year 1, and in Year 2 the increments were upto 7.6, 15.7, 5.8 and $23.8 \%$, respectively, over control. In village Panchgaon, shoot and root length, biomass and yield increased up to 18.8 ,
21.7, 26.3 and $13.7 \%$ in year 1 , and upto 7.6, 13.1, 15.8 and $16.0 \%$, respectively, in Year 2. In village Bari, shoot and root length, biomass and yield increased up to 21.1, 13.6, 28.8 and 10.9\% in Year 1, while in Year 2 the same were recorded to increase up to $16.6,11.3,26.2$ and $25.7 \%$, respectively, over control (Table 2b).

Table 2b. Influence of bacterial inoculation on growth and yield related parameters of Eleusine coracana recorded in three villages.

\begin{tabular}{|c|c|c|c|c|c|c|c|c|}
\hline \multicolumn{5}{|c|}{ Year 1} & \multicolumn{4}{|c|}{ Year 2} \\
\hline Treatment & $\begin{array}{c}\text { Shoot } \\
\text { length }(\mathrm{cm})\end{array}$ & $\begin{array}{c}\text { Root } \\
\text { length }(\mathrm{cm})\end{array}$ & $\begin{array}{l}\text { Biomass } \\
\quad(\mathrm{g})\end{array}$ & $\begin{array}{l}\text { Yield } \\
(\mathrm{g})\end{array}$ & $\begin{array}{c}\text { Shoot } \\
\text { length }(\mathrm{cm})\end{array}$ & $\begin{array}{c}\text { Root } \\
\text { length }(\mathrm{cm})\end{array}$ & $\begin{array}{l}\text { Biomass } \\
\quad(\mathrm{g})\end{array}$ & $\begin{array}{l}\text { Yield } \\
(\mathrm{g})\end{array}$ \\
\hline \multicolumn{9}{|c|}{ Katarmal } \\
\hline Control & $76.91 \pm 5.07$ & $18.33 \pm 2.53$ & $11.95 \pm 0.99$ & $4.12 \pm 0.76$ & $105.5 \pm 6.12$ & $18.47 \pm 2.26$ & $15.46 \pm 1.40$ & $4.80 \pm 0.49$ \\
\hline Inoculated & $85.79 \pm 6.89^{*}$ & $24.15 \pm 4.80^{*}$ & $16.28 \pm 2.49 *$ & $4.83 \pm 0.74$ & $114.21 \pm 9.80^{*}$ & $21.38 \pm 2.77 *$ & $18.38 \pm 2.17 *$ & $6.30 \pm 1.01 *$ \\
\hline ANOVA & $\begin{array}{c}F_{1,18}=5.06 \\
p=0.035\end{array}$ & $\begin{array}{c}F_{1,18}=7.35 \\
p=0.014\end{array}$ & $\begin{array}{l}F_{l, 18}=17.8 \\
p=0.0005\end{array}$ & $\begin{array}{c}F_{l, 18}=4.49 \\
p=0.048\end{array}$ & $\begin{array}{c}F_{l, 18}=5.17 \\
p=0.035\end{array}$ & $\begin{array}{c}F_{1,18}=6.58 \\
p=0.019\end{array}$ & $\begin{array}{c}F_{l, 18}=12.64 \\
p=0.002\end{array}$ & $\begin{array}{c}F_{1,18}=8.56 \\
p=0.009\end{array}$ \\
\hline \multicolumn{9}{|c|}{ Panchgaon } \\
\hline Control & $80.03 \pm 3.34$ & $19.85 \pm 2.34$ & $12.67 \pm 1.58$ & $4.49 \pm 0.63$ & $110.5 \pm 17.26$ & $20.55 \pm 1.16$ & $16.49 \pm 3.00$ & $5.08 \pm 0.83$ \\
\hline Inoculated & $98.60 \pm 7.36^{*}$ & $25.30 \pm 4.12 *$ & $17.19 \pm 4.44 *$ & $5.11 \pm 0.41$ & $135.5 \pm 2.34 *$ & $23.64 \pm 2.34 *$ & $19.54 \pm 2.70^{*}$ & $6.08 \pm 1.01 *$ \\
\hline ANOVA & $\begin{array}{c}F_{1,18}=9.63 \\
p=0.006\end{array}$ & $\begin{array}{c}F_{1,18}=5.19 \\
p=0.035\end{array}$ & $\begin{array}{c}F_{1,18}=9.18 \\
p=0.007\end{array}$ & $\begin{array}{c}F_{1,18}=6.58 \\
p=0.019\end{array}$ & $\begin{array}{c}F_{1,18}=7.22 \\
p=0.015\end{array}$ & $\begin{array}{c}F_{1,18}=1.89 \\
p=0.186\end{array}$ & $\begin{array}{c}F_{1,18}=5.56 \\
p=0.02\end{array}$ & $\begin{array}{c}F_{1,18}=7.90 \\
p=0.011\end{array}$ \\
\hline
\end{tabular}




\begin{tabular}{|c|c|c|c|c|c|c|c|c|}
\hline \multicolumn{5}{|c|}{ Year 1} & \multicolumn{4}{|c|}{ Year 2} \\
\hline Treatment & $\begin{array}{c}\text { Shoot } \\
\text { length }(\mathrm{cm})\end{array}$ & $\begin{array}{c}\text { Root } \\
\text { length }(\mathrm{cm})\end{array}$ & $\begin{array}{l}\text { Biomass } \\
(\mathrm{g})\end{array}$ & $\begin{array}{l}\text { Yield } \\
(\mathrm{g})\end{array}$ & $\begin{array}{c}\text { Shoot } \\
\text { length }(\mathrm{cm})\end{array}$ & $\begin{array}{c}\text { Root } \\
\text { length }(\mathrm{cm})\end{array}$ & $\begin{array}{l}\text { Biomass } \\
(\mathrm{g})\end{array}$ & $\begin{array}{l}\text { Yield } \\
(\mathrm{g})\end{array}$ \\
\hline \multicolumn{9}{|c|}{ Bari } \\
\hline Control & $82.91 \pm 6.29$ & $20.86 \pm 2.59$ & $12.82 \pm 12.8$ & $4.96 \pm 0.51$ & $115.56 \pm 15.80$ & $21.09 \pm 2.51$ & $18.07 \pm 1.44$ & $5.28 \pm 3.34$ \\
\hline Inoculated & $105.2 \pm 10.97 *$ & $24.1 \pm 4.37 *$ & $18.04 \pm 2.4^{*}$ & $5.53 \pm 0.52$ & $138.8 \pm 7.64 *$ & $23.78 \pm 3.39$ & $24.4 \pm 3.30 *$ & $7.02 \pm 0.86^{*}$ \\
\hline ANOVA & $\begin{array}{c}F_{1,18}=14.25 \\
p=0.001\end{array}$ & $\begin{array}{c}F_{1,18}=3.15 \\
p=0.092\end{array}$ & $\begin{array}{c}F_{1,18}=26.16 \\
p=7.24\end{array}$ & $\begin{array}{c}F_{1,18}=5.91 \\
p=0.02\end{array}$ & $\begin{array}{c}F_{1,18}=7.49 \\
p=0.013\end{array}$ & $\begin{array}{c}F_{1,18}=3.53 \\
p=0.07\end{array}$ & $\begin{array}{c}F_{1,18}=6.20 \\
p=0.022\end{array}$ & $\begin{array}{c}F_{1,18}=30.36 \\
p=3.13\end{array}$ \\
\hline
\end{tabular}

*significant at $p<0.05 \%$, values are the means $\pm \mathrm{SD}(\mathrm{n}=10)$.

In case of Echinochloa frumentacea in village Katarmal, shoot and root length, biomass and yield in inoculated plants were recorded to increase up to 20.4, 17.5, 34.1 and $4.6 \%$, respectively, in Year 1 and up to 10.6 , 8.4, 19.8 and 9.5\%, respectively, in Year 2. In village Panchgaon shoot and root length, biomass and yield increased up to 27.5, 22.9, 23.7 and 9.5\% in Year 1 and upto 17.4, 17.0, 20.6 and 4.7\%, respectively in Year 2 over control (Table 2c). The harvest index in the three crops grown in different villages ranged from 21.1 to 38.5 in control and 16.5 to 32.4 in inoculated plants, in Year 1, and from 12.6 to 31.2 in control and 10.5 to 34.4 in inoculated plants, in Year 2.

Table 2c. Influence of bacterial inoculation on growth and yield related parameters of Echinochloa frumentacea recorded in two villages.

\begin{tabular}{|c|c|c|c|c|c|c|c|c|}
\hline \multirow[b]{2}{*}{ Treatment } & \multirow[b]{2}{*}{$\begin{array}{c}\text { Shoot } \\
\text { length }(\mathrm{cm})\end{array}$} & \multicolumn{4}{|c|}{ Year 1} & \multicolumn{3}{|c|}{ Year 2} \\
\hline & & $\begin{array}{c}\text { Root } \\
\text { length }(\mathrm{cm})\end{array}$ & $\begin{array}{l}\text { Biomass } \\
(\mathrm{g})\end{array}$ & $\begin{array}{l}\text { Yield } \\
(\mathrm{g})\end{array}$ & $\begin{array}{c}\text { Shoot } \\
\text { length }(\mathrm{cm})\end{array}$ & $\begin{array}{c}\text { Root } \\
\text { length }(\mathrm{cm})\end{array}$ & $\begin{array}{l}\text { Biomass } \\
(\mathrm{g})\end{array}$ & $\begin{array}{l}\text { Yield } \\
(\mathrm{g})\end{array}$ \\
\hline \multicolumn{9}{|c|}{ Katarmal } \\
\hline Control & $61.84 \pm 8.65$ & $14.66 \pm 4.37$ & $7.72 \pm 1.47$ & $1.86 \pm 0.27$ & $118 \pm 7.07$ & $18.47 \pm 1.49$ & $14.91 \pm 2.87$ & $1.92 \pm 0.31$ \\
\hline Inoculated & $77.73 \pm 3.37^{*}$ & $17.73 \pm 4.37^{*}$ & $=11.77 \pm 3.72 *$ & $1.95 \pm 0.31$ & $132 \pm 6.76^{*}$ & $20.15 \pm 3.75$ & $18.69 \pm 2.86^{*}$ & $2.13 \pm 0.25$ \\
\hline ANOVA & $\begin{array}{c}F_{l, 18}=10.81 \\
p=0.001\end{array}$ & $\begin{array}{c}F_{1,18}=7.95 \\
p=0.011\end{array}$ & $\begin{array}{c}F_{1,18}=9.92 \\
p=0.005\end{array}$ & $\begin{array}{c}F_{1,18}=0.25 \\
p=0.62\end{array}$ & $\begin{array}{c}F_{1,18}=7.25 \\
p=0.021\end{array}$ & $\begin{array}{c}F_{1,18}=5.52 \\
p=0.011\end{array}$ & $\begin{array}{c}F_{1,18}=10.67 \\
p=0.004\end{array}$ & $\begin{array}{c}F_{1,18}=2.54 \\
p=0.128\end{array}$ \\
\hline \multicolumn{9}{|c|}{ Panchgaon } \\
\hline Control & $70.9 \pm 4.93$ & $16.19 \pm 3.37$ & $9.02 \pm 3.02$ & $1.92 \pm 0.31$ & $120.2 \pm 13.21$ & $19.56 \pm 4.11$ & $15.46 \pm 3.12$ & $2.0 \pm 0.14$ \\
\hline Inoculated & $97.85 \pm 7.63^{*}$ & $20.96 \pm 3.37^{*}$ & $=11.89 \pm 1.53 *$ & $2.10 \pm 0.25$ & $145.6 \pm 8.16^{*}$ & $23.50 \pm 3.00 *$ & $19.48 \pm 2.82 *$ & $2.1 \pm 0.23$ \\
\hline ANOVA & $\begin{array}{c}F_{1,18}=5.84 \\
p=0.026\end{array}$ & $\begin{array}{c}F_{1,18}=28.20 \\
p=04.76\end{array}$ & $\begin{array}{c}F_{1,18}=7.12 \\
p=0.015\end{array}$ & $\begin{array}{c}F_{1,18}=2.54 \\
p=0.012\end{array}$ & $\begin{array}{c}F_{1,18}=10.45 \\
p=0.022\end{array}$ & $\begin{array}{c}F_{1,18}=7.25 \\
p=0.041\end{array}$ & $\begin{array}{c}F_{1,18}=9.08 \\
p=0.007\end{array}$ & $\begin{array}{c}F_{1,18}=5.98 \\
p=0.02\end{array}$ \\
\hline
\end{tabular}

*significant at $p<0.05 \%$, values are the means $\pm \mathrm{SD}(\mathrm{n}=10)$. 


\subsection{Root colonization and microbial communities}

Increase in per cent root colonization by mycorrhizae and endophytes were recorded in inoculated plants, as compared to control, in both the years, at all the sites (Figure 1). Out of the two groups, increase was higher in case of endophytes ( 40 to $85 \%$ ) as compared to mycorrhizae (up to $30 \%$ ). Highest colonization of mycorrhizae and endophytes was recorded in crop1 (Oryza sativa) in village Bari, in both the years. In Year 1, mycorrhizal colonization was found to be 15 and $25 \%$ in control and inoculated plants, respectively, while $40 \%$ and $75 \%$ colonization by endophytes was recorded in control and inoculated plants, respec- tively. In Year 2, mycorrhizal colonization was found to be 15 and $30 \%$, in control and inoculated plants, while colonization by endophytes was 70 and $85 \%$, in control and inoculated plants, respectively.

The differences in microbial counts (bacteria, actinomycetes and fungi) due to bacterial inoculation are presented in Table 3. Statistically significant increases in the populations of bacteria and actinomycetes, in the rhizosphere inoculated plants as compared to control, were recorded in all the crops, across all sites. The increase was higher in case of bacteria, as compared to actinomycetes. On the other hand, lower fungal counts were recorded in the rhizosphere of inoculated plants, as compared to control.
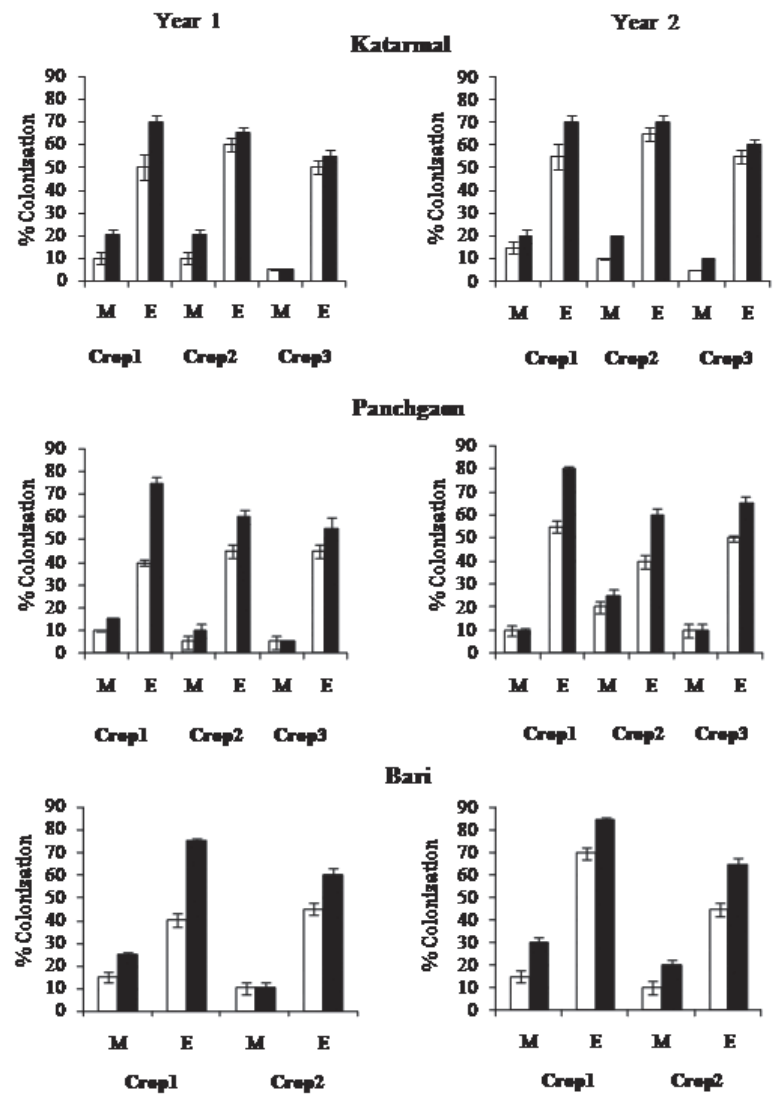

Figure 1. Percent colonization of mycorrhizae and endophytes in the roots of three crops. $M=$ Mycorrhizae, $E$ $=$ Endophytes. 
Table 3: Influence of bacterial inoculation on rhizosphere microbial population (CFU x $10^{-4} \mathrm{~g}^{-1}$ ) in all the three crops during two years.

\begin{tabular}{lcccccccc}
\hline & \multicolumn{7}{c}{ Katarmal } & \multicolumn{2}{c}{ Panchgaon } & Bari \\
\cline { 2 - 9 } & Crop 1 & Crop 2 & Crop 3 & Crop 1 & Crop 2 & Crop 3 & Crop 1 & Crop 2 \\
\hline \multicolumn{7}{c}{ Year 1 } \\
\hline $\begin{array}{l}\text { Control } \\
\text { (B) }\end{array}$ & $35.66 \pm 2.08$ & $39.66 \pm 2.08$ & $46.33 \pm 1.5$ & $33.33 \pm 1.52$ & $33.33 \pm 4.16$ & $36.66 \pm 2.30$ & $39.33 \pm 5.03$ & $39.66 \pm 2.08$ \\
$\begin{array}{l}\text { Inoculated } \\
\text { (B) }\end{array}$ & $44.33 \pm 4.04$ & $53.33 \pm 7.63 *$ & $57.66 \pm 2.5 *$ & $51.66 \pm 2.08 *$ & $51.33 \pm 3.60 * 56.33 \pm 1.52 *$ & $49.66 \pm 9.07 *$ & $48.66 \pm 3.21$ \\
$\begin{array}{l}\text { Control } \\
\text { (F) }\end{array}$ & $8.66 \pm 3.23 *$ & $11.66 \pm 1.52 *$ & $10.33 \pm 0.57 *$ & $11.33 \pm 1.52 *$ & $7.33 \pm 0.57$ & $10.33 \pm 0.57 *$ & $5.66 \pm 2.08$ & $10.33 \pm 2.08^{*}$ \\
$\begin{array}{l}\text { Inoculated } \\
\text { (F) }\end{array}$ & $2.33 \pm 0.57$ & $3.66 \pm 1.54$ & $2.66 \pm .057$ & $2.33 \pm 0.57$ & $6.33 \pm 0.57$ & $2.66 \pm 0.57$ & $2.33 \pm 0.57$ & $2.66 \pm 0.57$ \\
$\begin{array}{l}\text { Control (A) } \\
\text { Inoculated } \\
\text { (A) }\end{array}$ & $4.60 \pm 1.15$ & $4.66 \pm 0.57$ & $4.66 \pm 0.57$ & $4.66 \pm 0.57$ & $3.66 \pm 0.57$ & $4.66 \pm 1.52$ & $3.66 \pm 0.57$ & $4.66 \pm 1.15$ \\
\hline
\end{tabular}

Year 2

Control

(B)

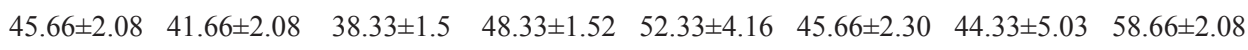
Inoculated $58.33 \pm 4.04 * 65.33 \pm 7.63 * 58.66 \pm 2.5 * 67.66 \pm 2.08 * 72.33 \pm 3.60 * 64.33 \pm 1.52 * 68.66 \pm 9.07 * 75.66 \pm 3.21 *$
(B)

Control

(F)

$11.66 \pm 3.2 * \quad 11.66 \pm 1.52 * 13.33 \pm 0.57 * 13.33 \pm 1.52 * \quad 7.33 \pm 0.57 \quad 10.33 \pm 0.57 * \quad 5.66 \pm 2.08 \quad 10.33 \pm 2.08 *$

Inoculated

(F)

$\begin{array}{llllllll}2.33 \pm 0.57 & 3.66 \pm 1.54 & 2.66 \pm .057 & 2.33 \pm 0.57 & 3.33 \pm 0.57 & 2.66 \pm 0.57 & 2.33 \pm 0.57 & 2.66 \pm 0.57\end{array}$

Control

(A)

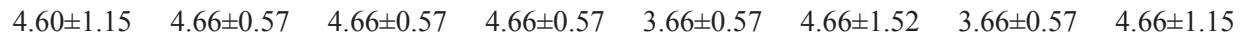

Inoculated

(A)

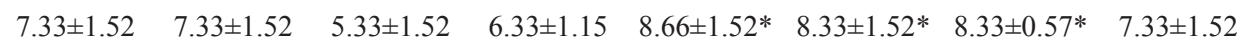

$(\mathrm{B})=$ Bacteria,$(\mathrm{F})=$ Fungi, $(\mathrm{A})=$ Actinomycetes, Crop 1: Oryza sativa, Crop 2: Eleusine coracana, Crop 3: Echinochloa frumentacea *significant at $p<0.05 \%$, values are the means $\pm \operatorname{SD}(\mathrm{n}=3)$.

\subsection{Chlorophyll content}

Chlorophyll content was found to increase in inoculated plants over control, in all the three crops, in both the years (Figure 2). Across villages, increase in the chlorophyll content of Oryza sativa leaves was found to range between 6.4 to $8.3 \%$ and 5.4 to $5.7 \%$, in Year 1 and Year 2, respectively. In case of crop Eleusine coracana, this increase ranged between 8.5 to $9.9 \%$ and 5.7 to $9.6 \%$, in Year 1 and Year 2, respectively. In Echinochloa frumentacea, the increase was found to range between 7.6 and 9.1 $\%$ and 8.8 to $10.2 \%$, in Year 1 and Year 2, respectively. 

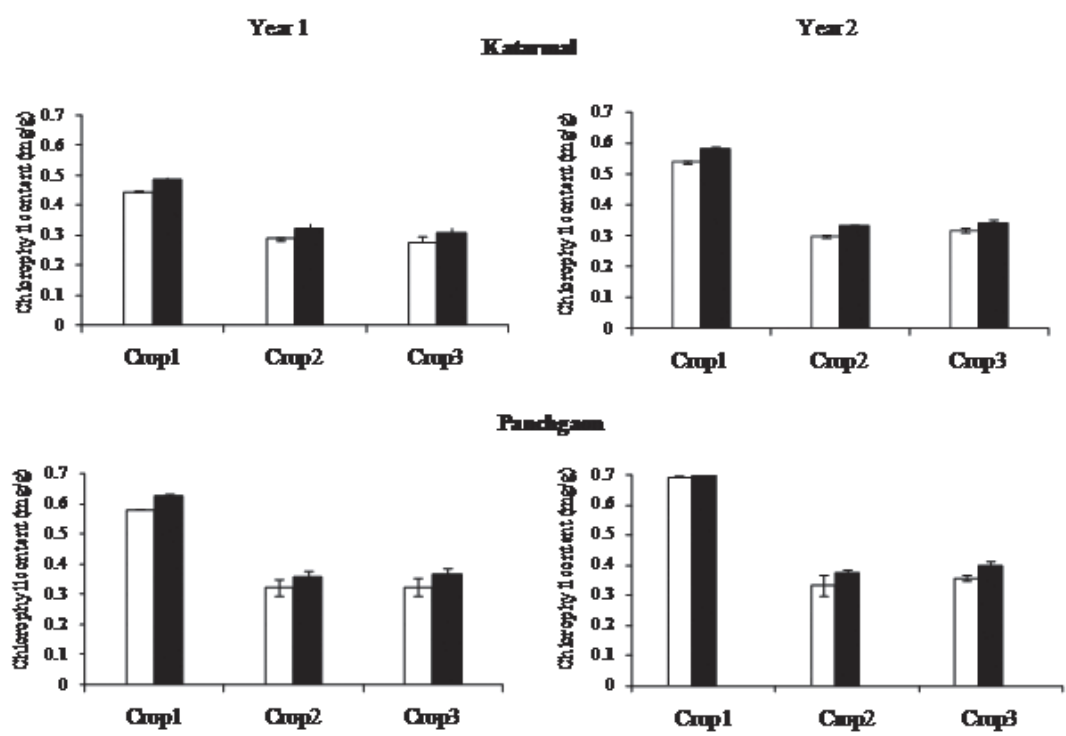

$\mathbf{R}-\mathbf{i}$
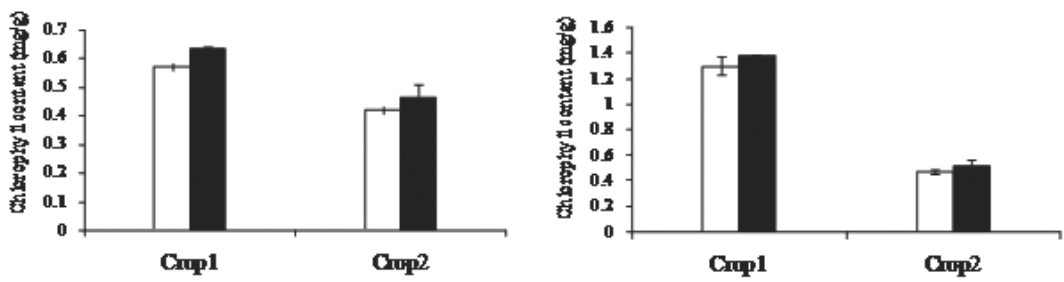

Figure 2. Total chlorophyll content in leaves of three crops.

\section{Discussion}

The present study summarizes the effect of bacterial inoculation on three locally important crops grown on farmers' fields, for two consecutive years in different villages under rainfed conditions at mountain locations. The positive effects of inoculations were reflected in terms of increase in length, height and biomass, and the overall crop yield. The relatively better performance in inoculation trials, recorded in the second year, may be attributed to somewhat higher rainfall. Besides, best plant performance recorded in village Bari, could also be attributed to relatively higher moisture content in this area, due to close proximity of river Kosi. These results are indicative of the influence of micro climatic factors, while evaluating PGPR trials in the agricultural fields, under mountain ecosystem, where, in general, the crops are exclusively dependant on the seasonal rainfall. Climatic variability influences the effect of PGPR applications (Okon and Labandera-Gonzalez, 1994). Data on harvest index exhibited that benefits of bacterial inoculations were both towards biological yield as well as crop residue, albeit higher in favour of crop residue. While the cereals in hills are grown mainly for grains, the millets are grown, in addition, for the fodder (and fuel) value of the residue. Thus, any 
increase in the crop residue is desirable for the sustenance of livestock. Similar results have been reported in a previous study conducted on some other hill crops (Pandey et al., 1999).

Various aspects of functional efficiency of PGPR have been studied extensively. The PGPR influence plant growth through direct or indirect mechanisms. The examples of direct mechanism(s) may include: growth promotion by providing fixed nitrogen to the host plant, phosphate solubilization, production of phytohormones, sequestration of iron by siderophores, and lowering of plant ethylene levels. The indirect mechanisms mainly involve biocontrol of plant pathogens that may be associated with antibiosis and production of antimicrobial substances, such as lytic enzymes and biocidal volatiles (Chaurasia et al., 2005; Compant et al., 2005). Natural agriculture ecosystems depend upon such beneficial microorganisms to sustain higher crop productivity (Rosas et al., 2009). Selection of early root colonizing PGPR, which directly or indirectly influence plant growth and productivity, is preferred (Cakmakci et al., 2006). The beneficial influence has been reported in terms of biofertilization, stimulation of root growth, rhizoremediation, plant stress management and biocontrol (Lugtenberg and Kamilova, 2009). Increase in plant growth related parameters including biochemicals, such as the chlorophyll content, due to bacterial inoculation in crop plants, under cold on highland areas of Turkey, has also been reported (Elkoca et al., 2008).

The ecological influence of the application of PGPR inoculant on native microflora, associated with the roots, has received considerable attention in recent times. The present study was conducted as an extension of a long term investigation to develop suitable microbial inoculants specifically for field application in the colder mountain regions. In the initial experiments, that were conducted under two climatic zones in the Mamlay watershed, Sikkim, on farmers' fields, it was observed that the bacterial inoculation stimulated the beneficial native populations of both gram negative (pseudomonads) and gram positive (actinomycetes) organisms, in the rhizosphere (Pandey et al., 1998). This concept was further established through pot as well as small scale field based assays (Pandey et al., 1999; Kumar et al., 2007), in another mountain state, Uttarakhand. From these experiments, it was concluded that the exogenous inoculant, when introduced in higher concentration, stimulates the native microflora that in turn influence the root (rhizosphere or rhizoplane, or both) colonization, subsequently affecting the plant growth. During interaction with the native microflora, the introduced bacterium is likely to compete for its own establishment in the rhizosphere. The phenomenon appears to be complex and is bound to bring a microbial shift in the rhizosphere. In the present study, it was observed that the bacterial inoculation increased not only the population of bacteria and actinomycetes, but also influenced the colonization of mycorrhizae and endophytes. While PGPR have received attention as mycorrhizae "helper bacteria", another important area related to plant growth promoting microbes receiving attention in recent literature pertains to colonization of internal tissues of plant species by the endophytes (Ryan et al., 2007). Suppression of fungal counts, observed in the present study, may be attributed to the known antifungal property of the bacterial inoculant (Chaurasia et al., 2005). Importance of quorum sensing in the rhizosphere with a view of determining the fate of the introduced bioinoculant in the natural ecosystem has also been studied (Sharma et al., 2003).

Based on the results of laboratory as well as field based studies, it was established that species of $\mathrm{Ba}$ cillus and Pseudomonas are suitable PGPRs for field application under low temperature environments. Both can be raised in suitable formulations and stored without the loss of the beneficial traits over storage 
(Trivedi et al., 2005; Trivedi and Pandey, 2008a). However, for field application, it is desirable to select a PGPR that benefits a large number of plant species, under a particular environment. Most of the commercially developed PGPR belong to the genus Bacillus, and among the genus, strains of $B$. subtilis have been recognized as PGPR, mainly because of their disease reducing ability and resistance to environmental stresses due to spore forming nature. The importance and preference for the Bacillus species in field applications is of late getting attention (Ghosh et al., 2003; Liu et al., 2006; Trivedi et al., 2008; Trivedi and Pandey, 2008b; Pandey et al., 2011; Zhao et al., 2011).

\section{Conclusion}

Agricultural practices in the mountain ecosystem are unique. On the basis of a series of experiments conducted over time, in the colder mountain ecosystem, the following conclusions can be drawn: (1) to manage the role of PGPR, understanding of the prevailing agricultural practices in various ecosystems, and farmers' perception is required, (2) initial isolation of naturally occurring microorganisms from the respective environment, where they may be subsequently used, followed by laboratory as well as field based screenings for final selection of the suitable organism, is essential, and (3) shift in the native microflora due to application of the exogenous PGPR needs further attention, focusing on the stimulation (or suppression) of the free living, symbiotic and endophytic organisms, (4) Bacillus subtilis (NRRL B-30408B), initially isolated from a mountain location, and evaluated for the desirable traits related to plant growth promotion and biocontrol, is recommended for field applications under mountain ecosystem, and (5) onfarm demonstration trials, in collaboration with the local farmers, following an integrated approach using suitable PGPR, in addition of other organic inputs and appropriate water management are essential for the spread of the technology for improving crop productivity. Further, it is highly desirable to establish 'production units' in the specific regions for large scale production of microbial inoculants as cottage industries, to take care of the "microbial needs" of the local stakeholders.

For advancement in the area of PGPR research, deeper understanding of the rhizosphere ecology, with focus on the microbial communication during plantmicrobe and microbe-microbe interactions, needs attention. Knowledge on these lines is likely to provide clues to many observations noted in respect of the 'microbial shift' in the rhizosphere microflora due to PGPR application.

\section{Acknowledgements}

Uttarakhand State Council for Science and Technology, Government of Uttarakhand, and the Ministry of Environment and Forest, Govt. of India are thanked for financial support.

\section{References}

Agnihotri, R.K., Chandra, S., Sharma, S., Palni L.M.S. 2000. Genetic variability in photosynthesis and chlorophyll content of various landraces of upland rice. IRRN. 25, 2, 13-14.

Allen, S.E. 1974. Chemical analysis of ecological materials. Blackwell Scientific publications. Oxford, pp. 81-159.

Cakmakci, R., Donmez, F., Aydin, A., Shin, F. 2006. Growth promotion of plants by plant growth-promoting rhizobacteria under greenhouse and two different field soil conditions. Soil Biol. Biochem. 38, 1482-1787.

Chaurasia, B., Pandey, A., Palni, L.M.S., Trivedi, P., Kumar, B., Colvin, N. 2005. Diffusible and vola- 
tile compounds produced by an antagonistic $\mathrm{Ba}$ cillus subtilis strain cause structural deformities in pathogenic fungi in vitro. Microbiol. Res. 160, 75-81.

Compant, S., Duffy, B., Nowak, J., Clement, C., Barka, E.A. 2005. Use of plant growth-promoting bacteria for biocontrol of plant diseases: Principles, mechanisms of action, and future prospects. Appl. Environ. Microbiol. 4951-4959.

Elkoca, E., Kantar, F., Sahin, F. 2008. Influence of nitrogen fixing and phosphorus solubilizing bacteria on the nodulation, plant growth, and yield of chickpea. J. Plant Nutr. 31, 157-171.

Farooquee, N.A., Maikhuri, R.K. 2009. Communities and their agrobiodiversity priorities for agriculture in Uttarakhand Himalaya, India. Outlook on Agriculture. 38, 383-389.

Ghosh, S., Penterman, J.N., Little, R.D., Chavez, R., Glick, B.R. 2003. Three newly isolated plant growth promoting bacilli facilitate the seedling growth of canola, Brassica campestris. Plant Physiol. Biochem. 41, 277-281.

Hiltner, L. 1904. Uber neuere Erfahrungen and Probleme auf dem Gebiet der Bodenbakteriologie und unter besonderer Berucksichtigung der Grundungung und Brache [German]. Arb Dtsch Landwirtsch Ges. 98, 59-78.

Kloepper, J.W., Lifshitz, R., Zablotowicz, R.M. 1989. Free living bacterial inocula for enhancing crop productivity. Trends Biotechnol. 7, 39-43.

Kumar, B., Trivedi, P., Pandey, A. 2007. Pseudomonas corrugata: A suitable bacterial inoculant for maize grown under rainfed conditions of Himalayan region. Soil Biol. Biochem. 39, 3093-3100.

Liu, X., Zhao, H., Chen, S. 2006. Colonization of maize and rice by strain Bacillus megaterium $\mathrm{C} 4$. Curr. Microbiol. 52, 186-190.
Lucy, M., Reed, E., Glick, B.R. 2004. Application of free living plant growth-promoting rhizobacteria. Antonie van Leeuweenhoek. 86, 1-25.

Lugtenberg, B.J.J., Kamilova, F. 2009. Plant growth promoting rhizobacteria. Annu. Rev. Microbiol. 63, 363-383.

Okon, Y., Labandera-Gonzalez, C.A. 1994. Agronomic applications of Azospirillum: an evaluation of 20 years worldwide field inoculation. Soil Biol. Biochem. 26, 1591-1601.

Pandey, A., Chaudhry, S., Sharma, A., Choudhary, V.S., Malviya, M.K., Chamoli, S., Rinu K., Trivedi, P., Palni, L.M.S. 2011. Recovery of Bacillus and Pseudomonas spp from the 'Fired Plots' under Shifting Cultivation in Northeast India. Curr. Microbiol. 62 ,1, 273-280.

Pandey, A., Durgapal, A., Joshi, M., Palni, L.M.S. 1999. Influence of Pseudomonas corrugata inoculation on root colonization and growth promotion of two important hill crops. Microbiol. Res. 154, 259-266.

Pandey, A., Palni, L.M.S., Bag, N. 2000. Biological hardening of tissue culture raised tea plants through rhizosphere bacteria. Biotechnol. Lett. 22, 1087-1091.

Pandey, A., Palni, L.M.S., Bisht, D. 2001a. Dominant fungi in the rhizosphere of established tea bushes and their interactions with the dominant bacteria under in situ conditions. Microbiol. Res. $156,377-382$.

Pandey, A., Palni, L.M.S., Coulomb, N. 1997. Antifungal activity of bacteria isolated from the rhizosphere of established tea bushes. Microbiol. Res. $152,1,105-112$.

Pandey, A., Palni, L.M.S., Hebbar, K.P. 2001b. Suppression of damping-off in maize seedlings by Pseudomonas corrugata. Microbiol. Res. 156, 191-194. 
Pandey, A., Palni, L.M.S., Mulkalwar, P., Nadeem, M. 2002. Effect of temperature on solubilization of tricalcium phosphate by Pseudomonas corrugata. J. Sci. Ind. Res. 61, 457-460.

Pandey, A., Sharma, E., Palni, L.M.S. 1998. Influence of bacterial inoculation on maize in upland farming systems of the Sikkim Himalaya. Soil Biol. Biochem. 30, 379-384.

Pandey, A, Trivedi, P., Kumar, B., Chaurasia, B., Singh, S., Palni, L.M.S. 2004. Development of microbial inoculants for enhancing plant performance in mountains. In: Reddy, M.S., Khanna, S., (eds). Biotechnological Approaches for Sustainable development. Allied Publishers Pvt. Limited, New Delhi, pp. 13-20.

Rinu, K., Pandey, A. 2009. Bacillus subtilis NRRL B-30408 inoculation enhances the symbiotic efficiency of Lens esculanta Moench at a Himalayan location. J. Plant Nutr. Soil Sci. 172, 134-139.

Rosas, S.R., Avanzini, G., Carlier, E., Pasluosta, C., Pastor, N., Rovera, M. 2009. Root colonization and growth promotion of wheat and maize by Pseudomonas aurantiaca SR1. Soil Biol. Biochem. 41, 1802-1806.

Rovira, A.D. 1991. Rhizosphere research- 85 years of progress and frustration, In: Keister, D.L. and Cregan, P.B., (eds). The rhizosphere and plant growth, Kluwer Academic Publishers, Netherlands, pp. 3-13.

Ryan, R.P., Germaine, K., Franks, A., Ryan, D.J, Dowling, D.N. 2007. Bacterial endophytes: recent developments and applications. FEMS Microbiol. Lett. 278, 1-9.

Sharma, A., Sahgal, M., Johri, B.N. 2003. Microbial communication in the rhizosphere: Operation of quorum sensing. Curr. Sci. 85, 1164-1172.

Trivedi, P., Kumar, B., Pandey, A. 2008. Nature and applications of Bacillus species for improving plant growth. In: Maheshwari, D.K., Dubey, R.C., (eds). Potential Microorganisms for sustainable agriculture: A Techno-commercial perspective, IK International Publishing House Pvt. Ltd, pp. 49-66.

Trivedi, P., Kumar, B., Pandey, A., Palni, L.M.S. 2007. Growth promotion of rice by phosphate solubilizing bioinoculants in a Himalayan location. In: Velazquez, E., Rodriguez-barrueco, C., (eds). Plant and Soil, Developments in Plant and Soil Sciences, first international meeting on microbial phosphate solubilization, Springer, Salamanca Spain, pp. 291-299.

Trivedi, P., Pandey, A. 2008a. Recovery of plant growth promoting rhizobacteria from sodium alginate beads after three years following storage at $4{ }^{\circ}$ C. J. Ind. Microbiol. Biotechnol. 35, 205-209.

Trivedi, P., Pandey, A. 2008b. Plant growth promotion abilities and formulation of Bacillus megaterium strain B 388 (MTCC6521) Isolated from a Temperate Himalayan Location. Ind. J. Microbiol. 48 $3,342-347$.

Trivedi, P., Pandey, A., Palni, L.M.S. 2005. Carrier based formulations of plant growth promoting bacteria suitable for use in the cooler regions. World J. Microbiol. Biotechnol. 26, 6-7, 941-945.

Trivedi, P., Pandey, A., Palni, L.M.S. 2012. Bacterial inoculants for field applications under Mountain Ecosystem: Present initiatives and future prospects. In: Maheshwari D.K. (ed). Bacteria in Agrobiology: Plant Probiotics, Springer, pp. 15-44.

Zhao, Q., Shen, Q., Ran, W., Xiao, T., Xu, D., Xu, Y. 2011. Inoculation of soil by Bacillus subtilis Y-IVI improves plant growth and colonization of the rhizosphere and interior tissues of muskmelon ( $\mathrm{Cu}$ cumis melo L.). Biol. Fertil. Soils. 47 5, 507-514. 